\title{
ANALISIS PENGARUH KELENGKAPAN FITUR, PERSEPSI KEMUDAHAN PENGGUNAAN, KUALITAS INFORMASI, KUALITAS SISTEM, PERSEPSI MANFAAT TERHADAP KEPUASAN PENGGUNAAN SERTA DAMPAKNYA TERHADAP LOYALITAS PENGGUNA APLIKASI VIU
}

\author{
Oleh: \\ Jenny Natalia \\ Dahlia Br Ginting ${ }^{1}$
}

E-mail : dahliaginting@yahoo.co.id ${ }^{1}$

\begin{abstract}
ABSTRAK
Tujuan dari penelitian ini adalah untuk menguji pengaruh kelengkapan fitur, kemudahan penggunaan, kualitas informasi, kualitas sistem, dan manfaat terhadap kepuasan pengguna aplikasi VIU dan dampaknya terhadap loyalitas pengguna.

Responden dalam penelitian ini adalah pengguna Viu di provinsi Jawa Barat dan teknik sampling yang digunakan teknik non-probability sampling dengan metode purposive sampling. Sampel dalam penelitian ini berjumlah 270 responden. Teknik pengumpulan data dilakukan dengan cara menyebarkan koisioner. Skala yang digunakan dalam penelitian ini adalah Skala Likert. Analisis yang dilakukan yaitu analisis deskriptif dan menggunakan analisis jalur.

Hasil penelitian ini menunjukkan adanya pengaruh kelengkapan fitur, kemudahan penggunaan, kualitas informasi, kualitas sistem, dan manfaat secara parsial terhadap kepuasan pengguna. Demikian juga kelengkapan fitur, persepsi kemudahan penggunaan, kualitas informasi, kualitas sistem, dan persepsi manfaat secara simultan berpengaruh terhadap kepuasan pengguna. Besarnya pengaruh kelengkapan fitur, kemudahan penggunaan, kualitas informasi, kualitas sistem, dan manfaat penggunaan aplikasi Viu secara simultan terhadap kepuasan pengguna sebesar 57.2\% .

Hasil penelitian juga menunjukkan adanya pengaruh kelengkapan fitur, kemudahan penggunaan, kualitas informasi, kualitas sistem, manfaat, dan kepuasan pengguna secara parsial terhadap loyalitas. Demikian juga kelengkapan fitur, kemudahan penggunaan, kualitas informasi, kualitas sistem, manfaat, dan kepuasan pengguna secara simultan berpengaruh terhadap loyalitas. Besarnya pengaruh kelengkapan fitur, kemudahan penggunaan, kualitas informasi, kualitas sistem, manfaat dan kepuasan pengguna aplikasi Viu secara simultan terhadap loyalitas pengguna sebesar $50.4 \%$.
\end{abstract}

Kata kunci : pengaruh kelengkapan fitur, kemudahan penggunaan, kualitas informasi, kualitas sistem, kepuasan penggunaan, aplikasi Viu

\section{PENDAHULUAN}

Perkembangan dunia hiburan (entertainment) terjadi secara pesat di berbagai belahan dunia, tak terkecuali di Indonesia. Maraknya perkembangan dunia hiburan tidak terlepas dari dukungan media elektronik dan teknologi. Seiring dengan kemajuan elektronik dan teknologi, dunia hiburan juga menjadi semakin maju. Berbagai jenis acara-acara yang 
ditampilkan pada media massa pun sangat mudah disaksikan oleh para penggemarnya. Media massa dan stasiun TV berlomba untuk menampilkan acara-acara atau siaran-siaran yang menarik perhatian para pemirsa, sperti Talk Show, film, sinetron, drama Asia dan yang lainnya.

Kemajuan teknologi yang ada sekarang, memudahkan konsumen untuk dapat mengetahui apa saja dunia hiburan yang sedang dan yang akan ditayangkan di negara lain. Aplikasi Viu menyediakan jasa mengunduh video secara offline seperti youtube melalui website aplikasinya.

Aplikasi Viu adalah layanan video over-the-top (OTT) yang dioperasikan oleh PCCW Media. Aplikasi Viu menyediakan drama Asia, program variasi, anime dan berita hiburan. Kerjasama dengan Telkomsel dan IndiHome di Indonesia, aplikasi Viu telah menyediakan pilihan secara gratis maupun premium untuk menonton video (film atau drama korea terbaru dan berbagai film lainnya) sesuai dengan keinginan penggunanya melalui berbagai perangkat (ponsel, tablet, desktop). Selain itu, pengguna juga dapat menonton video secara online atau mengunduhnya terlebih dahulu untuk kemudian menyaksikan secara offline.

Tujuan dari penelitian ini adalah untuk menguji pengaruh kelengkapan fitur, kemudahan penggunaan, kualitas informasi, kualitas sistem, dan manfaat terhadap kepuasan pengguna aplikasi VIU dan dampaknya terhadap loyalitas pengguna.

\section{TELAAH PUSTAKA}

\subsection{KELENGKAPAN FITUR APLIKASI INFORMASI}

Definisi fitur menurut Kotler dan Amstrong :

"Fitur adalah alat bersaing yang membedakan produk suatu perusahaan dengan perusahaan lainnya." (Kotler dan Amstrong, 2006:226).

Kelengkapan fitur menurut Ainscough dan Luckett adalah sebagai berikut:

"Perlengkapan untuk interaktivitas konsumen adalah kriteria penting yang menarik perhatian para konsumen di dalam penyampaian jasa internet." (Pranidana, 2011:21)

Kelengkapan fitur layanan adalah persepsi pengguna aplikasi yang telah disediakan. Adapun indikator variable kelengkapan fitur ini antara lain adalah kesesuaian fasilitas dengan kebutuhan, keamanan fasilitas dari virus computer, dan biaya penggunaan fasilitas (Amijaya, 2010:29)

\subsection{PERSEPSI KEMUDAHAN PENGGUNAAN}

Davis et al. (1989) mendefinisikan percieved ease of use sebagai keyakinan akan kemudahan penggunaan, yaitu tingkatan dimana user percaya bahwa teknologi atau sistem tersebut dapat digunakan dengan mudah dan bebas dari masalah. Intensitas penggunaan dan interaksi antara pengguna dengan sistem juga dapat menunjukkan kemudahan penggunaan. Beberapa indikator percieved ease of use menurut Davis et al (1989) yakni Ease of learn, Controllable, Clear and understandable, Flexible, Ease to become skillful, Ease to use dan Timeliness.

\subsection{KUALITAS INFORMASI}

Informasi yang digunakan untuk pengambilan keputusan oleh manajer harus merupakan informasi yang memiliki kualitas atau karakteristik informasi yang baik sehingga pengambilan keputusan tepat dan pada akhirnya dapat meningkatkan kinerja secara keseluruhan.

Bodnar (2003:10) dalam Nunuy (2004), dan Romney et al (1997:14) merangkum karakteristik informasi yang berkualitas diidentifikasikan meliputi : Relevant, Reliable, Complete, Timely, Understandable, dan Verifiable . (Widarsono, 2007) 


\subsection{KUALITAS SISTEM APLIKASI}

Menurut DeLone dan McLean (2003) kualitas sistem yaitu karakteristik dari informasi yang melekat mengenai sistem itu sendiri. Menurut Mulyanto (2009), kualitas sistem dapat diartikan bahwa karakteristik kualitas yang diinginkan pengguna dari sistem informasi itu sendiri. Kualitas sistem berarti kualitas dari kombinasi hardware dan software dalam sistem informasi. Berfokus kepada performa dari sistem itu sendiri, yang merunjuk pada seberapa baik kemampuan perangkat keras, perangkat lunak, kebijakan, dan prosedur dari sistem informasi dapat menyediakan informasi sesuai dengan kebutuhan pengguna.

Kualitas sistem dapat diukur melalui beberapa indikator yaitu : kemudahan untuk digunakan (ease of use), kecepatan akses (response time), keandalan sistem (reliability), fleksibilitas sistem (flexibility), dan keamanan sistem (security). (Yuniarto, 2007:4)

\subsection{PERSEPSI MANFAAT}

Davis et al. (1989) mendefinisikan perceived usefulness sebagai keyakinan akan kemanfaatan, yaitu tingkatan dimana user percaya bahwa penggunaan teknologi sistem akan meningkatkan performa mereka dalam bekerja.

Menurut Chin dan Todd (1995) dimensi kemanfaatan meliputi : pekerjaan lebih mudah (makes job easier), bermanfaat (usefull), menambah produktifitas (increase productivity) dan mempertinggi efektifitas (enchance efectiveness).

\subsection{KEPUASAN PENGGUNAAN}

Kepuasan pengguna sistem informasi merupakan respond umpan balik yang dimunculkan pengguna setelah memakai sistem informasi. Kepuasan konsumen merupakan salah satu inti filsafat konsep pemasaran. Kepuasan pelanggan merupakan salah satu faktor untuk mengukur keberhasilan bagi setiap pengembangan dan implimentasi sistem aplikasi informasi pada suatu perusahaan.

Beberapa indikator yg dapat digunakan untuk mengukur kepuasan pengguna menurut Siti Ning Farida (2014:100), yaitu:

a. Pengalaman, yakni suatu kegiatan yang pernah dilakukan atau dialami sehingga dapat menimbulkan kepuasan.

b. Harapan pengguna, yakni kesesuaian antara harapan pengguna dengan kinerja actual aplikasi.

c. Kebutuhan, yakni kesesuaian antara keperluan atau kebutuhan dengan aplikasi yang tersedia. Bila semua terpenuhi, maka akan timbul kepuasan.

(Festus, 2006)

\subsection{LOYALITAS}

Menurut Hidayat (2009:103) loyalitas pengguna merupakan komitmen seorang pengguna terhadap suatu aplikasi berdasarkan sikap positif dan tercermin dalam minat ulang penggunaan aplikasi secara konsisten. Indikator dari loyalitas pengguna tersebut antara lain : Trust, Emosion commitment, Switching cost, Word of mouth, dan Cooperation. 


\section{KERANGKA PEMIKIRAN TEORITIS DAN RUMUSAN HIPOTESIS}

Rumusan hipotesis dalam penelitian ini :

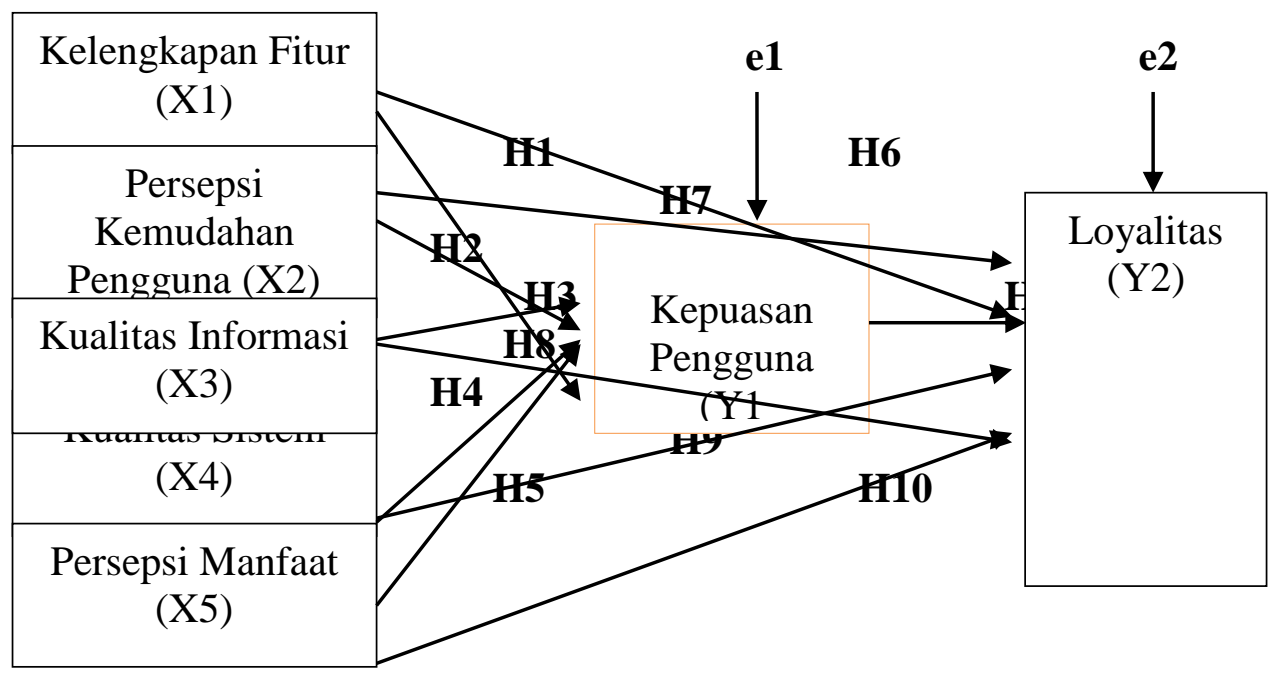

Gambar 1

Model Penelitian

$\mathrm{H}_{1}$ : Kelengkapan Fitur berpengaruh terhadap Kepuasan Penggunaan

$\mathrm{H}_{2}$ : Kemudahaan Penggunaan berpengaruh terhadap Kepuasan Pengguna

$\mathrm{H}_{3}$ : Kualitas Informasi berpengaruh terhadap Kepuasan Penggunaan

$\mathrm{H}_{4}$ : Kualitas Sistem berpengaruh terhadap Kepuasan Penggunaan

$\mathrm{H}_{5}$ : Manfaat berpengaruh terhadap Kepuasan Penggunaan

$\mathrm{H}_{6}$ : Kelengkapan Fitur berpengaruh terhadap Loyalitas

$\mathrm{H}_{7}$ : Kemudahaan Penggunaan berpengaruh terhadap Loyalitas

$\mathrm{H}_{8}$ : Kualitas Informasi berpengaruh terhadap Loyalitas

$\mathrm{H}_{9}$ : Kualitas Sistem berpengaruh terhadap Loyalitas

$\mathrm{H}_{10}$ : Manfaat berpengaruh terhadap Loyalitas.

$\mathrm{H}_{11}$ : Kepuasan Penggunaan berpengaruh terhadap Loyalitas

\section{ANALISIS JALUR}

Menurut Sarwono terdapat beberapa definisi analisis jalur, diantaranya :

"Analisis jalur adalah suatu teknik untuk menganalisis hubungan sebab akibat yang terjadi pada regresi berganda jika variabel bebasnya mempengaruhi variabel terikat tidak hanya secara langsung, tetapi secara tidak langsung." (Rutherford, 1993) 


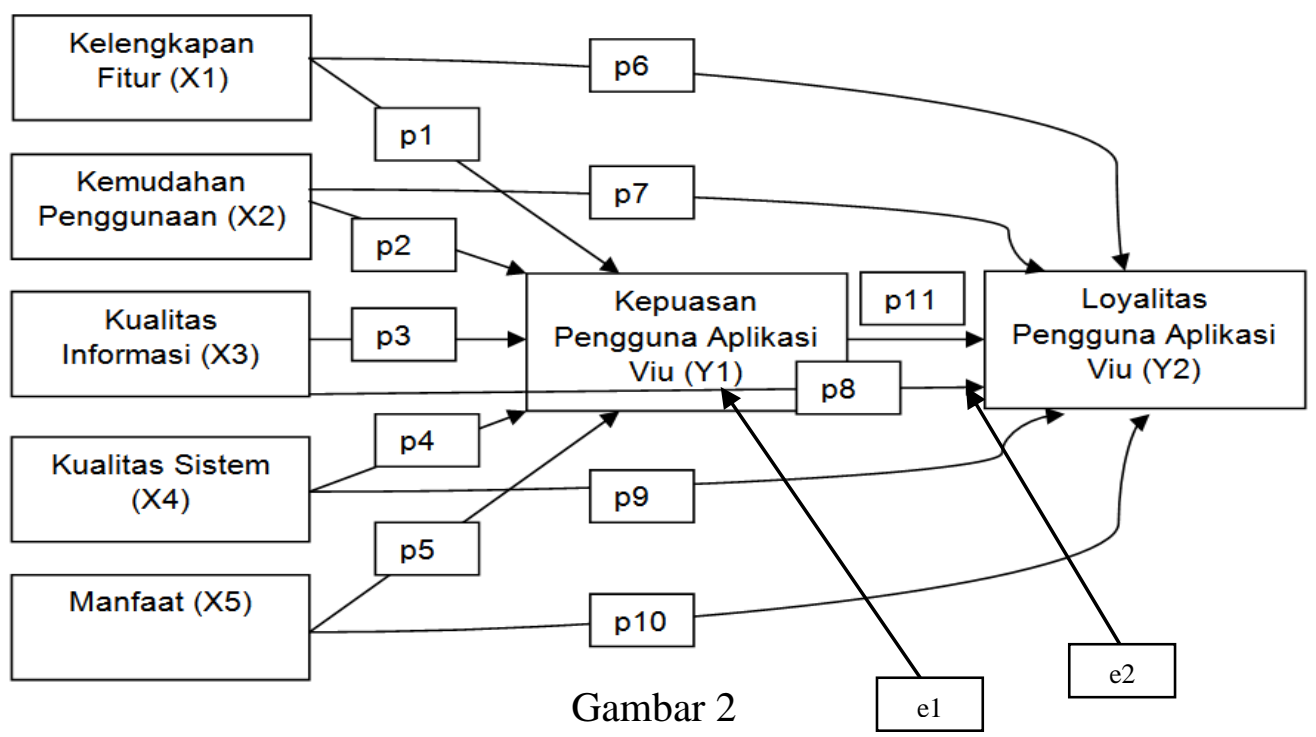

Bentuk Model Analisis Jalur

Regresi linear jalur pertama :

$$
Y_{1}=p_{1} x_{1}+p_{2} x_{2}+p_{3} x_{3}+p_{4} x_{4}+p_{5} x_{5}+e_{1}
$$

Regresi linear jalur kedua :

$$
Y_{2}=p_{6} x_{1}+p_{7} x_{2}+p_{8} x_{3}+p_{9} x_{4}+p_{10} x_{5}+p_{11} y_{1}+e_{2}
$$

\section{HASIL PENELITIAN DAN PEMBAHASAN}

Agar data yang diperoleh mempunyai tingkat akurasi dan konsistensi yang tinggi, instrumen penelitian yang digunakan harus valid dan reliabel (Sanusi, 2011).

\subsection{UJI VALIDITAS}

Uji validitas digunakan untuk mengetahui keabsahan suatu kuisioner atau untuk mengetahui valid atau tidaknya suatu butir pertanyaan. Dalam penelitian ini, suatu butir pertanyaan dianggap valid jika nilai indeks ( $\mathrm{r}$ hitung ) yang dihasilkan dari pengolahan SPSS lebih besar dari 0.4 (r kritis) dan signifikansi <0.05. (Wijaya, 2009:117)

Tabel 1

Hasil Uji Validitas Variabel-variabel Penelitian

\begin{tabular}{|c|l|c|c|c|c|}
\hline \multicolumn{2}{|c|}{ Item Pertanyaan } & $\begin{array}{c}\text { R } \\
\text { hitung }\end{array}$ & $\begin{array}{c}\text { R } \\
\text { kritis }\end{array}$ & Signifikansi & Kesimpulan \\
\hline \multirow{2}{*}{$\begin{array}{c}\text { Kelengkapan } \\
\text { fitur (X1) }\end{array}$} & $\begin{array}{l}\text { Kesesuian } \\
\text { fasilitas dengan } \\
\text { kebutuhan }\end{array}$ & 0.893 & 0.4 & 0.000 & Valid \\
\cline { 2 - 6 } & $\begin{array}{l}\text { Keamanan } \\
\text { fasilitas dari } \\
\text { virus komputer }\end{array}$ & 0.918 & 0.4 & 0.000 & Valid \\
\cline { 2 - 6 } & $\begin{array}{l}\text { Biaya } \\
\text { penggunaan } \\
\text { fasilitas }\end{array}$ & 0.921 & 0.4 & 0.000 & Valid \\
\hline \multirow{3}{*}{ Persepsi } & Ease of learn & 0.894 & 0.4 & 0.000 & Valid \\
\cline { 2 - 6 } & Controllable & 0.892 & 0.4 & 0.000 & Valid \\
\hline
\end{tabular}




\begin{tabular}{|c|c|c|c|c|c|}
\hline \multicolumn{2}{|c|}{ Item Pertanyaan } & \multirow{2}{*}{$\begin{array}{c}\begin{array}{c}\mathbf{R} \\
\text { hitung }\end{array} \\
0.922\end{array}$} & \multirow{2}{*}{$\begin{array}{c}\begin{array}{c}\mathbf{R} \\
\text { kritis }\end{array} \\
0.4\end{array}$} & \multirow{2}{*}{$\begin{array}{c}\text { Signifikansi } \\
0.000\end{array}$} & \multirow{2}{*}{$\begin{array}{c}\text { Kesimpulan } \\
\text { Valid }\end{array}$} \\
\hline $\begin{array}{l}\text { Kemudahan } \\
\text { Penggunaan }\end{array}$ & $\begin{array}{l}\text { Ease to become } \\
\text { skillful }\end{array}$ & & & & \\
\hline$(\mathrm{X} 2)$ & Timeleness & 0.863 & 0.4 & 0.000 & Valid \\
\hline \multirow{5}{*}{$\begin{array}{l}\text { Kualitas } \\
\text { Informasi } \\
\quad(\mathrm{X} 3)\end{array}$} & Relevant & 0.781 & 0.4 & 0.000 & Valid \\
\hline & Reliable & 0.890 & 0.4 & 0.000 & Valid \\
\hline & Complete & 0.832 & 0.4 & 0.000 & Valid \\
\hline & Understandable & 0.789 & 0.4 & 0.000 & Valid \\
\hline & Verifiable & 0.798 & 0.4 & 0.000 & Valid \\
\hline \multirow{5}{*}{$\begin{array}{l}\text { Kualitas } \\
\text { Sistem } \\
\text { (X4) }\end{array}$} & Ease of use & 0.741 & 0.4 & 0.000 & Valid \\
\hline & Response time & 0.875 & 0.4 & 0.000 & Valid \\
\hline & Reliability & 0.802 & 0.4 & 0.000 & Valid \\
\hline & Flexibility & 0.772 & 0.4 & 0.000 & Valid \\
\hline & Security & 0.766 & 0.4 & 0.000 & Valid \\
\hline \multirow{3}{*}{$\begin{array}{l}\text { Persepsi } \\
\text { Manfaat } \\
\text { (X5) }\end{array}$} & $\begin{array}{l}\text { Makes job } \\
\text { easier }\end{array}$ & 0.892 & 0.4 & 0.000 & Valid \\
\hline & Usefull & 0.922 & 0.4 & 0.000 & Valid \\
\hline & $\begin{array}{l}\text { Enchance } \\
\text { effectiveness }\end{array}$ & 0.895 & 0.4 & 0.000 & Valid \\
\hline \multirow{3}{*}{$\begin{array}{l}\text { Kepuasan } \\
\text { Pengguna } \\
\text { (Y1) }\end{array}$} & Pengalaman & 0.904 & 0.4 & 0.000 & Valid \\
\hline & Harapan & 0.912 & 0.4 & 0.000 & Valid \\
\hline & Kebutuhan & 0.899 & 0.4 & 0.000 & Valid \\
\hline \multirow{4}{*}{$\begin{array}{l}\text { Loyalitas } \\
\text { Pengguna } \\
\text { (Y2) }\end{array}$} & Trust & 0.868 & 0.4 & 0.000 & Valid \\
\hline & $\begin{array}{l}\text { Emosian } \\
\text { commitment }\end{array}$ & 0.878 & 0.4 & 0.000 & Valid \\
\hline & Switching cost & 0.915 & 0.4 & 0.000 & Valid \\
\hline & Word of mouth & 0.837 & 0.4 & 0.000 & Valid \\
\hline
\end{tabular}

Hasil analisis data pada tabel 1 , menunjukkan nilai $r$ hitung seluruh pertanyaan $>0.4$ serta taraf signifikansi $<0.05$ sehingga seluruh indikator dikatakan valid sebagai alat ukur variable.

\subsection{UJI RELIABILITAS}

Uji reliabilitas digunakan untuk menguji konsistensi data kuisioner yang merupakan indicator dari variabel penelitian. Suatu variabel dikatakan reliabel atau handal jika jawaban seseorang terhadap pernyataan adalah konsisten atau stabil dari waktu ke waktu. Adapun alat yang digunakan untuk mengukur reliabilitas adalahkoefisien nilai Cronbach's Alpha. Suatu variabel dikatakan reliabel, apabila hasil Cronbach's Alpha $>0.6$ (Wijaya, 2011:115-116).

Tabel 2

Hasil Uji Reliabilitas

\begin{tabular}{|l|c|c|}
\hline \multicolumn{1}{|c|}{ Variabel } & Cronbach's Alpha & Kesimpulan \\
\hline Kelengkapan Fitur & 0.896 & Reliabel \\
\hline Persepsi Kemudahan Penggunaan & 0.915 & Reliabel \\
\hline Kualitas Informasi & 0.875 & Reliabel \\
\hline Kualitas Sistem & 0.848 & Reliabel \\
\hline
\end{tabular}




\begin{tabular}{|l|c|c|}
\hline \multicolumn{1}{|c|}{ Variabel } & Cronbach's Alpha & Kesimpulan \\
\hline Persepsi Manfaat & 0.886 & Reliabel \\
\hline Kepuasan Pengguna & 0.896 & Reliabel \\
\hline Loyalitas & 0.896 & Reliabel \\
\hline
\end{tabular}

Hasil analisis data pada tabel 2 menghasilkan nilai koefisien Cronbach's Alpha $>0,6$ untuk variabel kelengkapan fiotur, persepsi kemudahan penggunaan, kualitas informasi, kualitas sistem, kepuasan penggunaan dan loyalitas pengguna. Dengan demikian dapat disimpulkan bahwa semua variabel dalam penelitian terbukti reliable yang menggambarkan konsistensi jawaban responden.

\subsection{ANALISIS JALUR}

Teknik analisis yang digunakan dalam penelitian ini adalah kuantitatif dengan analisis jalur yaitu suatu teknik untuk menganalisis pola hubungan antar variabel dengan tujuan untuk mengetahui pengaruh langsung maupun tidak langsung seperangkat variabel bebas terhadap variabel terikat.

\subsubsection{UJI-T UNTUK JALUR PERTAMA}

Uji-t dilakukan untuk mengetahui apakah terdapat hubungan secara parsial variabel kelengkapan fitur (X1), variabel kemudahan penggunaan (X2), variabel kualitas informasi (X3), variabel kualitas sistem (X4), dan variabel manfaat (X5). terhadap kepuasan pengguna (Y1).

Tabel 3

Hasil Uji-t Jalur Pertama

Coefficients ${ }^{\mathrm{a}}$

\begin{tabular}{|c|c|c|c|c|c|c|}
\hline & \multirow[t]{2}{*}{ Model } & \multicolumn{2}{|c|}{$\begin{array}{c}\text { Unstandardized } \\
\text { Coefficients }\end{array}$} & $\begin{array}{l}\text { Standardized } \\
\text { Coefficients }\end{array}$ & \multirow[t]{2}{*}{$\mathrm{T}$} & \multirow[t]{2}{*}{ Sig. } \\
\hline & & B & Std. Error & Beta & & \\
\hline \multirow{6}{*}{1} & (Constant) & 4.922 & .869 & & 5.665 & .000 \\
\hline & Total X1 & .884 & .074 & .793 & 8.140 & .015 \\
\hline & Total X2 & .634 & .060 & .472 & 6.221 & .027 \\
\hline & Total X3 & .730 & .050 & .544 & 7.613 & .040 \\
\hline & Total X4 & .531 & .053 & .388 & 5.485 & .014 \\
\hline & Total X5 & .650 & .068 & .452 & 6.733 & .044 \\
\hline
\end{tabular}

a. Dependent Variable: Total Y1

a. Uji-t variabel Kelengkapan Fitur (X1) terhadap variabel Kepuasan Pengguna (Y1). Hipotesis :

$\mathrm{H}_{0}$ : variabel kelengkapan fitur tidak berpengaruh secara signifikan terhadap kepuasan pengguna.

$\mathrm{H}_{1}$ : variabel kelengkapan fitur berpengaruh secara signifikan terhadap kepuasan pengguna.

$\mathrm{T}_{\text {hitung }}=8.140$ sedangkan $\mathrm{t}_{\text {tabel }}=1.969 . \mathrm{T}_{\text {tabel }}$ diperoleh dari tabel dengan derajat kebebasan 264 [n-(k+1)]. Nilai $\mathrm{k}=$ jumlah variabel bebas dan $\mathrm{n}=$ jumlah sampel.

Dari hasil perhitungan diperoleh $\mathrm{T}_{\text {hitung }}(8.140)>\mathrm{t}_{\text {kritis }}(1.969)$ maka $\mathrm{H} 0$ ditolak artinya variabel kelengkapan fitur berpengaruh secara signifikan terhadap variabel kepuasan pengguna. Atau nilai signifikansi variabel kelengkapan fitur adalah $0.015<0.05$ maka hipotesis nol $\left(\mathrm{H}_{0}\right)$ ditolak, kesimpulannya yaitu variabel kelengkapan fitur berpengaruh terhadap variabel kepuasan pengguna. 
b. Uji-t variabel Kemudahan Penggunaan (X2) terhadap variabel Kepuasan Pengguna (Y1)

Hipotesis:

$\mathrm{H}_{0}$ : variabel kemudahan penggunaan tidak berpengaruh secara signifikan terhadap

kepuasan pengguna.

$\mathrm{H}_{1}$ : variabel kemudahan penggunaan berpengaruh secara signifikan terhadap

kepuasan pengguna.

Dari hasil perhitungan diperoleh $\mathrm{T}_{\text {hitung }}(6.221)>\mathrm{t}_{\text {kritis }}$ (1.969) maka H0 ditolak artinya variabel kemudahan penggunaan berpengaruh secara signifikan terhadap variabel kepuasan pengguna. Atau nilai signifikansi variabel kelengkapan fitur adalah $0.027<$ 0.05 maka hipotesis nol $\left(\mathrm{H}_{0}\right)$ ditolak, kesimpulannya yaitu variabel kemudahan penggunaan berpengaruh terhadap variabel kepuasan pengguna.

c. Uji-t variabel Kualitas Informasi (X3) terhadap variabel Kepuasan Pengguna (Y1) Hipotesis : $\mathrm{H}_{0}$ : variabel kualitas informasi tidak berpengaruh secara signifikan terhadap kepuasan pengguna.

$\mathrm{H}_{1}$ : variabel kualitas informasi berpengaruh secara signifikan terhadap kepuasan pengguna.

Dari hasil perhitungan diperoleh $\mathrm{T}_{\text {hitung }}(7.613)>\mathrm{t}_{\mathrm{kritis}}(1.969)$ maka $\mathrm{H} 0$ ditolak artinya variabel kualitas informasi berpengaruh secara signifikan terhadap variabel kepuasan pengguna. Atau nilai signifikansi variabel kelengkapan fitur adalah $0.040<0.05$ maka hipotesis nol $\left(\mathrm{H}_{0}\right)$ ditolak, kesimpulannya yaitu variabel kualitas informasi berpengaruh terhadap variabel kepuasan pengguna.

d. Uji-t variabel Kualitas Sistem (X4) terhadap variabel Kepuasan Pengguna (Y1)

Hipotesis :

$\mathrm{H}_{0}$ : variabel kualitas sistem tidak berpengaruh secara signifikan terhadap kepuasan pengguna.

$\mathrm{H}_{1}$ : variabel kualitas sistem berpengaruh secara signifikan terhadap kepuasan pengguna.

Dari hasil perhitungan diperoleh $\mathrm{T}_{\text {hitung }}(5.485)>\mathrm{t}_{\text {kritis }}(1.969)$ maka $\mathrm{H} 0$ ditolak artinya variabel kualitas sistem berpengaruh secara signifikan terhadap variabel kepuasan pengguna. Atau nilai signifikansi variabel kelengkapan fitur adalah 0.014 lebih kecil dari 0.05 maka hipotesis nol $\left(\mathrm{H}_{0}\right)$ ditolak, kesimpulannya yaitu variabel kualitas sistem berpengaruh terhadap variabel kepuasan pengguna.

e. Uji-t variabel Manfaat (X5) terhadap variabel Kepuasan Pengguna (Y1)

Hipotesis:

$\mathrm{H}_{0}$ : variabel manfaat tidak berpengaruh secara signifikan terhadap kepuasan pengguna.

$\mathrm{H}_{1}$ : variabel manfaat berpengaruh secara signifikan terhadap kepuasan pengguna.

Dari hasil perhitungan diperoleh $\mathrm{T}_{\text {hitung }}(6.733)>\mathrm{t}_{\text {kritis }}(1.969)$ maka $\mathrm{H} 0$ ditolak artinya variabel manfaat berpengaruh secara signifikan terhadap variabel kepuasan pengguna. Atau nilai signifikansi variabel kelengkapan fitur adalah 0.044 lebih kecil dari 0.05 maka hipotesis nol $\left(\mathrm{H}_{0}\right)$ ditolak, kesimpulannya yaitu variabel manfaat berpengaruh terhadap variabel kepuasan pengguna.

\subsubsection{UJI-T UNTUK JALUR KEDUA}

Uji-T digunakan untuk melihat pengaruh secara parsial variabel kelengkapan fitur (X1), variabel kemudahan penggunaan (X2), variabel kualitas informasi (X3), variabel 
kualitas sistem (X4), variabel manfaat (X5), kepuasan pengguna (Y1). Terhadap variabel loyalitas (Y2).

Tabel 4

Hasil Uji-t Jalur Kedua

Coefficients $^{\mathrm{a}}$

\begin{tabular}{|c|c|c|c|c|c|}
\hline \multirow[t]{2}{*}{ Model } & \multicolumn{2}{|c|}{$\begin{array}{c}\text { Unstandardized } \\
\text { Coefficients }\end{array}$} & $\begin{array}{c}\text { Standardized } \\
\text { Coefficients }\end{array}$ & \multirow[t]{2}{*}{ t } & \multirow[t]{2}{*}{ Sig. } \\
\hline & B & $\begin{array}{l}\text { Std. } \\
\text { Error }\end{array}$ & Beta & & \\
\hline (Constant) & 4.539 & .937 & & 4.845 & .000 \\
\hline Total X1 & .055 & .075 & .051 & 2.735 & .013 \\
\hline Total X2 & .079 & .062 & .085 & 3.282 & .021 \\
\hline Total X3 & .031 & .050 & .037 & 2.996 & .035 \\
\hline Total X4 & .221 & .054 & .265 & 4.088 & .000 \\
\hline Total X5 & .447 & .069 & .391 & 6.468 & .000 \\
\hline Total Y1 & .209 & .063 & .174 & 3.334 & .001 \\
\hline
\end{tabular}

a. Dependent Variable: Total Y2

a. Uji-t variabel Kelengkapan Fitur (X1) terhadap variabel Loyalitas (Y2)

Hipotesis :

$\mathrm{H}_{0}$ : variabel kelengkapan fitur tidak berpengaruh secara signifikan terhadap loyalitas.

$\mathrm{H}_{1}$ : variabel kelengkapan fitur berpengaruh secara signifikan terhadap loyalitas.

Dari hasil perhitungan diperoleh $\mathrm{T}_{\text {hitung }}(2.735)>\mathrm{t}_{\text {kritis }}(1.969)$ maka $\mathrm{H} 0$ ditolak artinya variabel kelengkapan fitur berpengaruh secara signifikan terhadap variabel loyalitas. Atau nilai signifikansi variabel kelengkapan fitur adalah 0.013 lebih kecil dari 0.05 maka hipotesis nol $\left(\mathrm{H}_{0}\right)$ ditolak, kesimpulannya yaitu variabel kelengkapan fitur berpengaruh terhadap variabel loyalitas.

b. Uji-t variabel Kemudahan Penggunaan (X2) terhadap variabel Loyalitas (Y2)

Hipotesis :

$\mathrm{H}_{0}$ : variabel kemudahan penggunaan tidak berpengaruh secara signifikan terhadap loyalitas.

$\mathrm{H}_{1}$ : variabel kemudahan penggunaan berpengaruh secara signifikan terhadap loyalitas. Dari hasil perhitungan diperoleh $\mathrm{T}_{\text {hitung }}(3.282)>\mathrm{t}_{\text {kritis }}(1.969)$ maka $\mathrm{H} 0$ ditolak artinya variabel kemudahan penggunaan berpengaruh secara signifikan terhadap variabel loyalitas. Atau nilai signifikansi variabel kelengkapan fitur adalah 0.021 lebih kecil dari 0.05 maka hipotesis nol $\left(\mathrm{H}_{0}\right)$ ditolak, kesimpulannya yaitu variabel kemudahan penggunaan berpengaruh terhadap variabel loyalitas.

c. Uji-t variabel Kualitas Informasi (X3) terhadap variabel Loyalitas (Y2)

Hipotesis :

$\mathrm{H}_{0}$ : variabel kualitas informasi tidak berpengaruh secara signifikan terhadap loyalitas.

$\mathrm{H}_{1}$ : variabel kualitas informasi berpengaruh secara signifikan terhadap loyalitas.

Dari hasil perhitungan diperoleh $\mathrm{T}_{\text {hitung }}(2.966)>\mathrm{t}_{\text {kritis }}(1.969)$ maka H0 ditolak artinya variabel kualitas informasi berpengaruh secara signifikan terhadap variabel loyalitas. Atau nilai signifikansi variabel kelengkapan fitur adalah 0.035 lebih kecil dari 0.05 maka hipotesis nol $\left(\mathrm{H}_{0}\right)$ ditolak, kesimpulannya yaitu variabel kualitas informasi berpengaruh terhadap variabel loyalitas. 
d. Uji-t variabel Kualitas Sistem (X4) terhadap variabel Loyalitas (Y2)

Hipotesis :

$\mathrm{H}_{0}$ : variabel kualitas sistem tidak berpengaruh secara signifikan terhadap loyalitas.

$\mathrm{H}_{1}$ : variabel kualitas sistem berpengaruh secara signifikan terhadap loyalitas.

Dari hasil perhitungan diperoleh $\mathrm{T}_{\text {hitung }}(4.088)>\mathrm{t}_{\mathrm{kritis}}$ (1.969) maka $\mathrm{H} 0$ ditolak artinya variabel kualitas sistem berpengaruh secara signifikan terhadap variabel loyalitas. Atau nilai signifikansi variabel kelengkapan fitur adalah 0.000 lebih kecil dari 0.05 maka hipotesis nol $\left(\mathrm{H}_{0}\right)$ ditolak, kesimpulannya yaitu variabel kualitas sistem berpengaruh terhadap variabel loyalitas.

e. Uji-t variabel persepsin Manfaat (X5) terhadap variabel Loyalitas (Y2)

Hipotesis :

$\mathrm{H}_{0}$ : variabel persepsi manfaat tidak berpengaruh secara signifikan terhadap loyalitas.

$\mathrm{H}_{1}$ : variabel persepsi manfaat berpengaruh secara signifikan terhadap loyalitas.

Dari hasil perhitungan diperoleh $\mathrm{T}_{\text {hitung }}(6.468)>\mathrm{t}_{\mathrm{kritis}}(1.969)$ maka $\mathrm{H} 0$ ditolak artinya variabel manfaat berpengaruh secara signifikan terhadap variabel loyalitas. Atau nilai signifikansi variabel kelengkapan fitur adalah 0.000 lebih kecil dari 0.05 maka hipotesis nol $\left(\mathrm{H}_{0}\right)$ ditolak, kesimpulannya yaitu variabel manfaat berpengaruh terhadap variabel loyalitas.

f. Uji-t variabel Kepuasan Pengguna (Y1) terhadap variabel Loyalitas (Y2)

Hipotesis:

$\mathrm{H}_{0}$ : variabel kepuasan pengguna tidak berpengaruh secara signifikan terhadap

loyalitas.

$\mathrm{H}_{1}$ : variabel kepuasan pengguna berpengaruh secara signifikan terhadap loyalitas.

Dari hasil perhitungan diperoleh $\mathrm{T}_{\text {hitung }}(3.334)>\mathrm{t}_{\text {kritis }}$ (1.969) maka H0 ditolak artinya variabel kepuasan pengguna berpengaruh secara signifikan terhadap Atau nilai signifikansi variabel kelengkapan fitur adalah 0.000 lebih kecil dari 0.05 maka hipotesis nol $\left(\mathrm{H}_{0}\right)$ ditolak, kesimpulannya yaitu variabel kepuasan pengguna berpengaruh terhadap variabel loyalitas.

\subsection{UJI-F}

Uji-F digunakan untuk mengetahui pengaruh secara simultan variabel independent yakni kelengkapan fitur (X1), kemudahan pengguna (X2), kualitas informasi (X3), kualitas sistem (X4) dan manfaat (X5) terhadap variabel kepuasan pengguna (Y1).

\subsubsection{UJI-F JALUR PERTAMA}

Tabel 5

Hasil Uji-F Jalur Pertama

ANOVA $^{\mathrm{a}}$

\begin{tabular}{|rl|r|r|r|r|r|}
\hline \multicolumn{1}{|l|}{ Model } & \multicolumn{1}{c|}{$\begin{array}{c}\text { Sum of } \\
\text { Squares }\end{array}$} & \multicolumn{1}{c|}{ Df } & \multicolumn{1}{c|}{$\begin{array}{c}\text { Mean } \\
\text { Square }\end{array}$} & F & Sig. \\
\hline \multirow{2}{*}{1} & Regression & 533.166 & 5 & 106.633 & 12.174 & $.000^{\mathrm{b}}$ \\
& Residual & 2312.330 & 264 & 8.759 & & \\
& Total & 2845.496 & 269 & & & \\
\hline
\end{tabular}

a. Dependent Variable: Total Y1

b. Predictors: (Constant), Total X1, Total X2, Total X3, Total X4, Total X5 
Hipotesis :

$\mathrm{H}_{0}$ : variabel kelengkapan fitur, kemudahan pengguna, kualitas informasi, kualitas sistem dan manfaat secara serentak tidak berpengaruh terhadap kepuasan pengguna.

$\mathrm{H}_{1}$ : variabel kelengkapan fitur, kemudahan pengguna, kualitas informasi, kualitas sistem dan manfaat secara serentakberpengaruh terhadap kepuasan pengguna.

Diperoleh $\mathrm{F}_{\text {hitung }}=12.174$ sedangkan $\mathrm{F}_{\text {tabel }}=3.029 . \mathrm{F}_{\text {tabel }}$ diperoleh dari tabel dgn menggunakan taraf signifikansi 5\% dan derajat kebebasan $264[\mathrm{n}-(\mathrm{k}+1)]$. Nilai $\mathrm{k}=$ jumlah variabel bebas $\mathrm{n}=$ jumlah sampel.

Berdasarkan hasil perhitungan diperoleh $F_{\text {hitung }}(12.174)>F_{\text {tabel }}$ (3.029) maka H0 ditolak artinya variabel kelengkapan fitur, kemudahan pengguna, kualitas informasi, kualitas sistem dan manfaat berpengaruh secara serentak terhadap variabel kepuasan pengguna. Atau nilai signifikansi variabel kelengkapan fitur, kemudahan pengguna, kualitas informasi, kualitas sistem dan manfaat adalah $0.000<0.05$, maka hipotesis nol $\left(\mathrm{H}_{0}\right)$ ditolak, kesimpulannya yaitu variabel kelengkapan fitur, kemudahan pengguna, kualitas informasi, kualitas sistem dan manfaat mempunyai pengaruh signifikan terhadap variabel kepuasan pengguna.

\subsubsection{UJI-F JALUR KEDUA}

Uji-F untuk menguji pengaruh variabel kelengkapan fitur (X1), kemudahan pengguna (X2), kualitas informasi (X3), kualitas sistem (X4), manfaat (X5) dan kepuasan pengguna (Y1) secara simultan terhadap variabel dependent loyalitas (Y2).

Tabel 6

Hasil Uji-F Jalur Kedua

ANOVA $^{\mathrm{a}}$

\begin{tabular}{|r|c|r|r|r|r|}
\hline Model & $\begin{array}{c}\text { Sum of } \\
\text { Squares }\end{array}$ & Df & \multicolumn{1}{c|}{$\begin{array}{c}\text { Mean } \\
\text { Square }\end{array}$} & F & Sig. \\
\hline \multirow{2}{*}{1 Regression } & 1713.654 & 6 & 285.609 & 31.452 & $.000^{\mathrm{b}}$ \\
Residual & 2388.213 & 263 & 9.081 & & \\
& 4101.867 & 269 & & & \\
\hline
\end{tabular}

a. Dependent Variable: Total Y2

Hipotesis:

$\mathrm{H}_{0}$ : variabel kelengkapan fitur, kemudahan pengguna, kualitas informasi, kualitas sistem, manfaat dan kepuasan pengguna secara serentak tidak berpengaruh terhadap loyalitas.

$\mathrm{H}_{1}$ : variabel kelengkapan fitur, kemudahan pengguna, kualitas informasi, kualitas sistem, manfaat dan kepuasan pengguna secara serentak berpengaruh terhadap loyalitas.

Berdasarkan hasil perhitungan diperoleh $F_{\text {hitung }}$ (31.452) $>F_{\text {tabel }}$ (3.030) maka H0 ditolak artinya variabel kelengkapan fitur, kemudahan pengguna, kualitas informasi, kualitas sistem, manfaat dan kepuasan pengguna berpengaruh secara serentak terhadap variabel loyalitas. Atau nilai signifikansi variabel kelengkapan fitur, kemudahan pengguna, kualitas informasi, kualitas sistem, manfaat dan kepuasan pengguna adalah $0.000<0.05$ maka hipotesis nol $\left(\mathrm{H}_{0}\right)$ ditolak, kesimpulannya yaitu variabel kelengkapan fitur, kemudahan pengguna, kualitas informasi, kualitas sistem, manfaat dan kepuasan pengguna secara simultan mempunyai pengaruh terhadap variabel loyalitas.

\subsection{HASIL ANALISIS KOEFISIEN REGRESI}

Model jalur yang digunakan dalam penelitian ini adalah model regresi berganda yang melibatkan lebih dari satu variabel bebas. Hasil model analisis jalur setelah pengolahan data: 


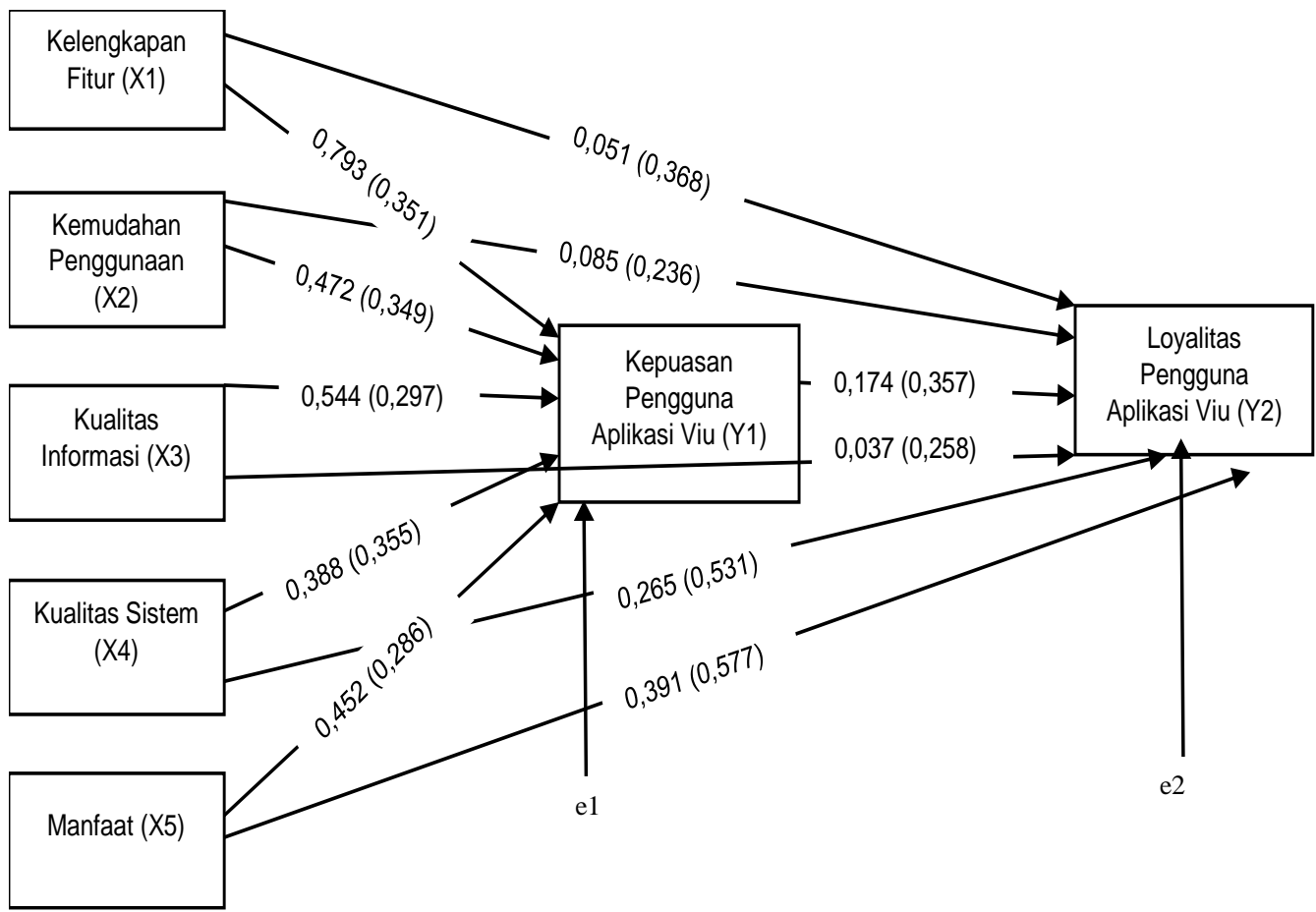

Gambar 3

Model Penelitian Setelah Pengolahan Data

Hasil analisis regresi pengaruh kelengkapan fitur, persepsi kemudahan penggunaan, kualitas informasi, kualitas sistem dan persepsi manfaat terhadap kepuasan pengguna.

Persamaan Sub Struktur Jalur Pertama :

$$
Y_{1}=0,793 x_{1}+0,472 x_{2}+0,544 x_{3}+0,388 x_{4}+0,452 x_{5}+0,428
$$

Koefisien regresi kelengkapan fitur, persepsi kemudahan penggunaan, kualitas informasi, kualitas sistem dan persepsi manfaat semuanya bertanda positif (berpengaruh positif), yang menunjukkan jika adanya peningkatan kelengkapan fitur, persepsi kemudahan pengguna, kualitas informasi, kualitas sistem dan persepsi manfaat alpikasi Viu maka akan meningkatkan kepuasan pengguna.

Hasil analisis regresi pengaruh kelengkapan fitur, persepsi kemudahan penggunaan, kualitas informasi, kualitas sistem ,persepsi manfaat dan kepuasan pengguna terhadap loyalitas pengguna.

Persamaan sub struktur jalur kedua :

$$
Y_{2}=0,051 x_{1}+0,085 x_{2}+0,037 x_{3}+0,265 x_{4}+0,391 x_{5}+0,174 y_{1}+0,496
$$

Hasil koefisien regresi jalur kedua semuanya bertanda positif (berpengaruh positif), yang menunjukkan adanya peningkatan kelengkapan fitur, kemudahan pengguna, kualitas informasi, kualitas sistem, manfaat dan kepuasan pengguna alpikasi Viu maka akan diikuti peningkatkan loyalitas pengguna.

\subsection{KOEFISIEN DETERMINASI}

Koefisien determinasi diperlukan untuk mengetahui seberapa besar pengaruh yang diberikan variabel bebas terhadap variabel terikatnya 
Tabel 7

Hasil Koefisien Determinasi Jalur Pertama

Model Summary ${ }^{b}$

\begin{tabular}{|l|r|r|r|r|}
\hline $\begin{array}{l}\text { Mode } \\
1\end{array}$ & \multicolumn{1}{|c|}{$\mathrm{R}$} & R Square & $\begin{array}{c}\text { Adjusted R } \\
\text { Square }\end{array}$ & $\begin{array}{l}\text { Std. Error of } \\
\text { the Estimate }\end{array}$ \\
\hline 1 & $.633^{\mathrm{a}}$ & .587 & .572 & 2.960 \\
\hline
\end{tabular}

Berdasarkan tabel 4 diperoleh Adjusted R Square sebesar 0.572 yang berarti $57.2 \%$ pengaruh secara simultan variabel kelengkapan fitur, kemudahan pengguna, kualitas informasi, kualitas sistem, dan terhadap kepuasan pengguna aplikasi Viu. Sisanya $42.8 \%\left(\sqrt{1-0,572^{2}}\right)$ dipengaruhi oleh variabel lain yang tidak diteliti dalam penelitian ini.

Tabel 8

Hasil Koefisien Determinasi Jalur Kedua

\begin{tabular}{|c|c|c|c|c|}
\hline \multicolumn{5}{|c|}{ Model Summary ${ }^{b}$} \\
\hline $\begin{array}{l}\text { Mode } \\
1\end{array}$ & $\mathrm{R}$ & R Square & $\begin{array}{c}\text { Adjusted R } \\
\text { Square }\end{array}$ & $\begin{array}{l}\text { Std. Error of } \\
\text { the Estimate }\end{array}$ \\
\hline 1 & $.646^{\mathrm{a}}$ & .518 & .504 & 3.013 \\
\hline
\end{tabular}

Berdasarkan tabel 5 diperoleh Adjusted R Square yang diperoleh 0.504 yang berarti $50.4 \%$ pengaruh secara simultan variabel kelengkapan fitur, kemudahan pengguna, kualitas informasi, kualitas sistem, manfaat, dan kepuasan pengguna terhadap loyalitas aplikasi Viu. Sisanya $49.6 \%\left(\sqrt{1-0,504^{2}}\right)$ dipengaruhi oleh variabel lain yang tidak diteliti dalam penelitian ini.

Analisis koefisien regresi rantai kausal pertama adalah :

a. Kelengkapan fitur terhadap kepuasan pengguna

Kelengkapan fitur memberi pengaruh langsung pada kepuasan sebesar 0.793. Hubungan antara kelengkapan fitur dengan kepuasan adalah 0.358 (hubungan positif ).

b. Persepsi kemudahan penggunaan terhadap kepuasan pengguna

Persepsi kemudahan penggunaan memberi pengaruh langsung pada kepuasan sebesar 0.472. Hubungan antara kemudahan penggunaan dengan kepuasan adalah 0.349 ( hubungan positif ).

c. Kualitas informasi terhadap kepuasan pengguna

Kualitas informasi memberi pengaruh langsung pada kepuasan sebesar 0.544 . Hubungan antara kepercayaan dengan kepuasan adalah 0.297 (hubungan positif ).

d. Kualitas sistem terhadap kepuasan pengguna

Kualitas sistem memberi pengaruh langsung pada kepuasan sebesar 0.388 Hubungan antara kualitas sistem dengan kepuasan adalah 0,355 ( hubungan positif )

e. Persepsi manfaat terhadap kepuasan pengguna

Persepsi manfaat memberi pengaruh langsung pada kepuasan sebesar 0.452 Hubungan antara kualitas sistem dengan kepuasan adalah 0,286 (hubungan positif)

Analisis koefisien regresi rantai kausal kedua adalah :

a. Kelengkapan fitur terhadap loyalitas pengguna

Kelengkapan fitur memberi pengaruh langsung padaloyalitas pengguna sebesar 0.0,051. Hubungan antara kelengkapan fitur dengan loyalitas pengguna adalah 0.368 (hubungan positif). 
b. Persepsi kemudahan penggunaan terhadap loyalitas pengguna

Persepsi kemudahan penggunaan memberi pengaruh langsung pada loyalitas pengguna sebesar 0.085 . Hubungan antara kemudahan penggunaan dengan loyalitas pengguna adalah 0.236 ( hubungan positif ).

c. Kualitas informasi terhadap loyalitas pengguna

Kualitas informasi memberi pengaruh langsung pada loyalitas pengguna sebesar 0.037. Hubungan antara kepercayaan dengan kepuasan adalah 0.258 (hubungan positif ).

d. Kualitas sistem terhadap kepuasan pengguna

Kualitas sistem memberi pengaruh langsung pada kepuasan sebesar 0.265 Hubungan antara kualitas sistem dengan kepuasan adalah 0,531 ( hubungan positif )

e. Persepsi manfaat terhadap kepuasan pengguna

Persepsi manfaat memberi pengaruh langsung pada kepuasan sebesar 0.391 Hubungan antara kualitas sistem dengan kepuasan adalah 0,577 ( hubungan positif )

f. Kepuasan pengguna terhadap loyalitas pengguna

Kepuasan pengguna memberi pengaruh langsung pada loyalitas pengguna sebesar 0.174 . Hubungan antara kepuasan pengguna dengan loyalitas pengguna adalah 0,357 (hubungan positif).

\subsection{PENGARUH TIDAK LANGSUNG}

Pada sub bab ini akan diuraikan pengaruh tidak langsung yang berkaitan dengan penelitian ini diantaranya adalah kelengkapan fitur (X1), kemudahaan penggunaan (X2), kualitas informasi (X3), kualitas sistem (X4), manfaat (X5) terhadap loyalitas pengguna (Y2) melalui kepuasan pengguna (Y1) aplikasi viu.

Tabel 9

Pengaruh Tidak Langsung

\begin{tabular}{|c|c|c|c|}
\hline Variabel & $\begin{array}{c}\text { Koefisien X } \\
\text { ke Y1 (a) }\end{array}$ & $\begin{array}{c}\text { Koefisien } \\
\text { Y1 ke Y2 } \\
\text { (b) }\end{array}$ & $\begin{array}{c}\text { Pengaruh Tidak } \\
\text { Langsung (a)*(b) }\end{array}$ \\
\hline $\mathrm{X} 1$ & 0.793 & 0.174 & 0.138 \\
\hline $\mathrm{X} 2$ & 0.472 & 0.174 & 0.082 \\
\hline $\mathrm{X} 3$ & 0.544 & 0.174 & 0.095 \\
\hline $\mathrm{X} 4$ & 0.388 & 0.174 & 0.068 \\
\hline $\mathrm{X} 5$ & 0.452 & 0.174 & 0.079 \\
\hline
\end{tabular}

Pengaruh Tidak Langsung :

a. Kelengkapan Fitur (X1) memiliki pengaruh tidak langsung terhadap loyalitas (Y2) melalui kepuasan pengguna (Y1) sebesar 0.138.

b. Kemudahan Penggunaan (X2) memiliki pengaruh tidak langsung terhadap loyalitas (Y2) melalui kepuasan pengguna (Y1) sebesar 0.082 .

c. Kualitas Informasi (X3) memiliki pengaruh tidak langsung terhadap loyalitas (Y2) melalui kepuasan pengguna (Y1) sebesar 0.095.

d. Kualitas Sistem (X4) memiliki pengaruh tidak langsung terhadap loyalitas (Y2) melalui kepuasan pengguna (Y1) sebesar 0.068.

e. Manfaat (X5) memiliki pengaruh tidak langsung terhadap loyalitas (Y2) melalui kepuasan pengguna (Y1) sebesar 0.079 . 
KESIMPULAN

Berdasarkan hasil penelitian yang telah dilakukan mengenai Analisis Pengaruh

Kelengkapan Fitur, Kemudahan Penggunaan, Kualitas Informasi, Kualitas Sistem, Manfaat Terhadap Kepuasan Penggunaan Aplikasi Serta

Dampaknya Terhadap Loyalitas Pengguna Aplikasi Viu diperoleh kesimpulan :

a. Ada pengaruh secara parsial (individu) antara kelengkapan fitur, kemudahan penggunaan, kualitas informasi, kualitas sistem, dan manfaat terhadap kepuasan pengguna apllikasi Viu.

b. Ada pengaruh secara simultan (bersama-sama) antara kelengkapan fitur, kemudahan penggunaan, kualitas informasi, kualitas sistem, dan manfaat terhadap kepuasan pengguna apllikasi Viu.

Koefisien determinasi sebesar 0,572, yang menunjukkan bahwa sebesar 57,2\% kepuasan pengguna dipengaruhi oleh kelengkapan fitur, kemudahan penggunaan, kualitas informasi, kualitas sistem, dan manfaat, sisanya sebesar 42,8\% dipengaruhi oleh variabel lain dalam penelitian ini.

c. Ada pengaruh secara parsial (individu) antara kelengkapan fitur, kemudahan penggunaan, kualitas informasi, kualitas sistem, manfaat, dan kepuasan pengguna terhadap loyalitas pengguna apllikasi Viu.

d. Ada pengaruh secara simultan (bersama-sama) antara kelengkapan fitur, kemudahan penggunaan, kualitas informasi, kualitas sistem, manfaat, dan kepuasan pengguna terhadap loyalitas pengguna apllikasi Viu.

Koefisien determinasi sebesar 0,504, yang menunjukkan bahwa sebesar 50,4\% loyalitas pengguna dipengaruhi oleh kelengkapan fitur, kemudahan penggunaan, kualitas informasi, kualitas sistem, manfaat, dan kepuasan pengguna, sisanya sebesar 49,6\% dipengaruhi oleh variabel lain dalam penelitian ini.

e. Kelengkapan Fitur (X1) memiliki pengaruh tidak langsung terhadap loyalitas (Y2) melalui kepuasan pengguna (Y1) sebesar 13,8\%. Kemudahan Penggunaan (X2) memiliki pengaruh tidak langsung terhadap loyalitas (Y2) melalui kepuasan pengguna (Y1) sebesar 8,2\%. Kualitas Informasi (X3) memiliki pengaruh tidak langsung terhadap loyalitas (Y2) melalui kepuasan pengguna (Y1) sebesar 9,5\%. Kualitas Sistem (X4) memiliki pengaruh tidak langsung terhadap loyalitas (Y2) melalui kepuasan pengguna (Y1) sebesar 6,8\%. Manfaat (X5) memiliki pengaruh tidak langsung terhadap loyalitas (Y2) melalui kepuasan pengguna (Y1) sebesar 7,9\%.

\section{DAFTAR PUSTAKA}

Amijaya, Gilang Rizky. 2010. Pengaruh Persepsi Teknologi Informasi, Kemudahan, Resiko dan Fitur Layanan Terhadap Loyalitas Nasabah Bank Dalam Menggunakan Internet Banking. Semarang.

Asep M, MM Puji Isyanto, dan Eli Irma. 2012. Analisis Kepuasan Pelanggan Terhadap Loyalitas Konsumen Rental DVD Club Cabang Tuparev-Karawang.

Auraningtyas. 2012. Pengaruh Computer Self Efficacy, Persepsi Manfaat, dan Kemudahaan Penggunaan Terhadap Kepuasan Penggunaan Sistem Informasi Akuntansi. Yogyakarta: Universitas Negeri Yogyakarta.

Davis, F.D., Bagozzi, R.P., and Warshaw, P.R., 1989. User acceptance of computer technology: A comparison of two theoretical models. Management Science, Vol. 35 No. 8 Agustus 1989 
DeLone, W.H., dan E.R. McLean. 2003. Information System Success: The Quest for Business, MIS Quarterly, 12(1):51-61.

Dewi, L. N. G. D. N., Jatra. M. 2013. Pengaruh Atribut Produk Terhadap Keputusan Pembelian Handphone di Kota Denpasar. E-Jornal Manajemen Universitas Udayana. Vol. 2 No. 2: 248-261.

Fatta, Khairul, et al. 2015. Pengaruh Harga, Citra Merek, dan Fitur Terhadap Kepuasan Konsumen Serta Dampaknya Pada Loyalitas Merek Handphone Samsung di Banda Aceh. Vol. 4 No.3. Agustus 2015.

Fendini, Dian Septiayu, et al 2013. Pengaruh Kualitas Sistem dan Kualitas Informasi Terhadap Kepuasan Pengguna (Survei Pada Karyawan Pengguna Aplikasi Pelayanan Pelanggan Terpusat (AP2T) di PT. PLN (Persero) Area Malang. Jurnal. Universitas Brawijaya Malang.

Fradana, Aditya. (2011). Pengaruh Kualitas Sistem Informasi, Perceived Ease of Use, dan Perceived Usefulness terhadap 27 Kepuasan Pengguna Software Akuntansi.

Hanuraga, Risang. (2011). Pengaruh Kebermanfaatan dan Kemudahan E-Learning Be Smart Terhadap Penerimaan Pengguna Pada Mahasiswa Akuntansi UNY.

Hidayat, Rachmad. 2009. Pengaruh Kualitas Layanan, Kualitas Produk dan Nilai Nasabah Terhadap Kepuasan dan Loyalitas Nasabah Bank Mandiri. Jurnal Manajemen dan Kewirausahaan. (Vol. 11 No. 1 Maret 2009).

Indriani, Mirna. 2009. Pengaruh Kualitas Sistem dan Kepuasan Pengguna Terhadap Loyalitas Pada Sistem Informasi Perguruan Tinggi Syiah Kuala. Jurnal Telaah dan Riset Sistem Infromasi. Vol. 2 No.1. Januari 2009. Hal 79-92.

Kotler, Philip dan Gary Amstrong. 2006. Prinsip-Prinsip Pemasaran. Jilid 1 dan 2. Edisi kedua belas. Jakarta: Erlangga.

Mulyanto, Agus. 2009. Sistem Informasi Konsep dan Aplikasi. Yogyakarta: Pustaka Pelajar.

Pranidana, Sauca Ananda. 2011. Analisis Faktor-Faktor yang Mempengaruhi Minat Nasabah Bank BCA untuk Menggunakan Klik-BCA. Semarang: Fakultas Ekonomi Universitas Diponegoro.

Rahadi, Dedi Rianto. 2007. Peranan Teknologi Informasi dalam Peningkatan Pelayanan di Sektor Publik. Yogyakarta: Universitas Bina Darma.

Risdiyanto, Anggih. 2014. Pengaruh Kualitas Infromasi, Kualitas Sistem, dan Kualitas Layanan Terhadap Kepuasan Pengguna Pada Sistem Informasi Klinik. Jurnal Program Studi Pendidikan Teknik Informatika. Yogyakarta, hlm. 56-57.

Romney, Marshal B., dan Steinbart, Paul John. 2009. Accounting Information Systems. USA: Cengage Learning.

Ruiz, M.M.R., Gil, S.I., Berenguer, C.G. 2009. Relational Benefits and Loyality in Retailing: an Inter-Sector Comparison. Internasional Journal of Marketing and Distribution Management. Vol. 37 No. 6: pg. 493-509.

Rutherford, Robert D dan Minja Kim Choe. 1993. Statistical Model For Causal Analysis. New York: John Wiley and Sons. Inc.

Sanusi, Anwar. 2011. Metodologi Penelitian Bisnis. Jakarta: Salemba Empat. 
Sudarti, Ken. 2013. Pengaruh Citra, Kualitas Informasi, dan Harga Terhadap Loyalitas Pelanggan Studi Kasus Pada Restoran Lombok Ijo Semarang. Vol 8 No. 2. Desember 2013. Hal 81-102.

Susanto, Herry dan Henky Setya Anggriawan. 2010. Analysis of Service Quality, Trust, and Information Quality To Loyality at Yudha Bhakti Online

Webley, Paul dan Stephan Lea. 1997. Path Analysis, Exeter. UK: Depertment Of Psychology, University Of Exeter.

Widarsono, Agus. 2007. Pengaruh Kualitas Informasi Manajemen Terhadap Kinerja Manajerial. Jurnal Akuntansi FE Unsil Vol. 2 No.2. Bandung.

Wijaya, Tony. 2009. Analisis Data Penelitian Menggunakan SPSS. Yogyakarta : Universitas Atma Jaya Yogyakarta

Wijaya, Tony. 2011. Manajemen Kualitas Jasa. Jakarta: PT. Indeks.

Yunianto, Yanuar. 2007. Penerimaan Sistem Online Public Access Catalog (OPAC) di Perpustakan Universitas Airlangga Kampus B. Departemen Ilmu Informasi dan Perpustakan. 